\title{
MicroRNAs in inflammatory lung disease - master regulators or target practice?
}

Irene K Oglesby, Noel G McElvaney ${ }^{\dagger}$, Catherine M Greene ${ }^{* \dagger}$

\begin{abstract}
MicroRNAs (miRNAs) have emerged as a class of regulatory RNAs with immense significance in numerous biological processes. When aberrantly expressed miRNAs have been shown to play a role in the pathogenesis of several disease states. Extensive research has explored miRNA involvement in the development and fate of immune cells and in both the innate and adaptive immune responses whereby strong evidence links miRNA expression to signalling pathways and receptors with critical roles in the inflammatory response such as NF- $\kappa \mathrm{B}$ and the toll-like receptors, respectively. Recent studies have revealed that unique miRNA expression profiles exist in inflammatory lung diseases such as cystic fibrosis, chronic obstructive pulmonary disease, asthma, idiopathic pulmonary fibrosis and lung cancer. Evaluation of the global expression of miRNAs provides a unique opportunity to identify important target gene sets regulating susceptibility and response to infection and treatment, and control of inflammation in chronic airway disorders. Over 800 human miRNAs have been discovered to date, however the biological function of the majority remains to be uncovered. Understanding the role that miRNAs play in the modulation of gene expression leading to sustained chronic pulmonary inflammation is important for the development of new therapies which focus on prevention of disease progression rather than symptom relief. Here we discuss the current understanding of miRNA involvement in innate immunity, specifically in LPS/TLR4 signalling and in the progression of the chronic inflammatory lung diseases cystic fibrosis, COPD and asthma. miRNA in lung cancer and IPF are also reviewed.
\end{abstract}

\section{Introduction}

Inflammatory lung diseases encompass a range of conditions which can be divided into acute and chronic diseases. Acute inflammatory lung diseases, for example pneumonia, in large part are triggered by environmental stimuli without the contribution of a genetic factor. Airway disorders associated with persistent inflammation such as cystic fibrosis (CF), chronic obstructive pulmonary disease (COPD) and asthma are classed as chronic conditions and are influenced by a combination of environmental, genetic and epigenetic components [1]. Infections causing severe systemic inflammation, depending on the magnitude of the initial stimulus can be short lived dissipating within days or weeks [2], whereas the sustained inflammation observed in CF, COPD and asthma can elicit deleterious effects leading to lung tissue damage, a constant need for medication and poor quality

\footnotetext{
* Correspondence: cmgreene@rcsi.ie

† Contributed equally

Respiratory Research Division, Department of Medicine, Royal College of Surgeons in Ireland, Beaumont Hospital, Dublin, Ireland
}

of life. Dysregulated inflammation is also observed in lung cancer and IPF and collectively with CF, COPD and asthma these conditions account for a huge percentage of deaths worldwide and hence there is an increasing need for the development of new therapies.

Elements of signalling pathways activated during the progression of chronic inflammation in the lung represent a vast area for miRNA studies. Although still in its infancy the involvement of miRNA in inflammatory lung diseases is becoming rapidly apparent (Table 1 ). Several investigators have implicated negative feedback control of inflammation via both regulators of inflammatory signalling and miRNA induction which we refer to later on in the review. We also discuss the biogenesis of miRNA and their role in the acquired and innate immune response highlighting specifically those linked to LPS/TLR4 signalling. We describe inflammatory lung disease in CF, COPD and asthma and explore what is currently known about miRNA and its role in the pathogenesis of these debilitating conditions along with a brief look at miRNA in lung cancer and IPF. 
Table 1 Selected miRNA implicated in inflammatory lung disease

\begin{tabular}{|c|c|c|c|c|c|}
\hline miRNA & Tissue/Cell Type & Species & Condition/treatment & Validated Target Genes & References \\
\hline$\underline{\text { Let-7d }}$ & Lung biopsies & Human & IPF & HMGA2 & {$[124]$} \\
\hline \multirow[t]{4}{*}{ miR-21 } & Whole lung & Mouse & Asthma & IL-12p35 & [94] \\
\hline & Macrophages & & & & \\
\hline & Dendritic cells & & & & \\
\hline & Lung biopsies & Human & IPF & Smad, Smad7 & {$[125]$} \\
\hline \multirow[t]{2}{*}{ miR-126 } & Primary bronchial epithelial cells & Human & CF & TOM1, Tollip & {$[112]$} \\
\hline & Lower airway tissue & Mouse & Asthma & OBF.1 & {$[120]$} \\
\hline miR-133a & Bronchial smooth muscle cells & Human & Asthma & RhoA & [97] \\
\hline miR-146a & Lung alveolar epithelial cells & Human & $\mathrm{IL}-1 \beta$ & IL-8, RANTES & {$[67]$} \\
\hline miR-218 & Primary bronchial epithelial cells & Human & CSE & MAFG & {$[87]$} \\
\hline miR148a,b, Human miR-152 & Primary bronchial epithelial cells & & Asthma & HLA-G & [24] \\
\hline \# Let-7c miR-34c miR-222 & Whole lung & Rat & CSE & ND & {$[86]$} \\
\hline $\begin{array}{l}\text { miR-26b, 27a, miR-31*, 96, } \\
\text { miR-135b,274a, } \\
\text { miR-338-5p, 494, } \\
\text { miR-513a-5p, b, c, } \\
\text { miR-923 }\end{array}$ & Primary bronchial epithelial cells & Human & DEP & ND & [88] \\
\hline $\begin{array}{l}\text { Let-7a, b, f, } \\
\text { miR-26a, 30b, c, } \\
\text { miR-34b, 99b, 122a, } \\
\text { miR-124a, 125a, b, 140, } \\
\text { miR-192, } 431\end{array}$ & Whole lung & Mouse & CSE & ND & {$[85]$} \\
\hline
\end{tabular}

CSE; cigarette smoke extract, ND; not determined, DEP; diesel exhaust particulate, \# 3 of 24 down-regulated miR's validated by qRT-PCR.

\section{miRNA background}

The discovery of miRNA is considered one of the major breakthroughs of the last decade. However they were probably first mentioned in the 1960's when Britten and Davidson proposed the existence of "activator" RNAs transcribed from redundant genomic regions [3]. In 1993 the first miRNA lin-4 was discovered in C.elegans [4] and it wasn't until eight years later that again in C.elegans the highly conserved let-7 was found to be crucial for developmental timing [5]. The term microRNA was coined when a large number of these small RNAs with potential regulatory roles were discovered in 2001 [6]. The following year established the presence of miRNAs in plants [7]. Subsequently miR-15 and miR-16 were shown to be deleted or down-regulated in chronic lymphocytic leukemias [8] suggesting miRNA involvement in cancer in humans.

MiRNAs are small, endogenous RNAs, approximately 20-25 nucleotides long which negatively regulate gene expression at a post-transcriptional level. They exert direct effects on gene expression by inducing mRNA degradation or translation inhibition and recently have been reported to act by indirect means through global effects on methylation or targeting of transcription factors $[9,10]$. Up-regulation of gene translation by miRNAs has also been reported albeit to a lesser extent, where
miR-369-3 for example, has been shown to switch from mRNA repression to activation in quiescent cell populations [11]. Interest in miRNAs over the past decade has increased exponentially uncovering their importance in biological processes such as development, proliferation and apoptosis. Relatively few miRNAs have been studied in detail and hence the precise biological relevance of the majority remains to be uncovered. It is estimated that up to one third of the human genome may be subject to regulation by miRNAs. Expression levels vary greatly among tissues and it is believed that dysregulation of miRNAs can contribute to disease pathology [12].

\section{miRNA - origin, processing and target selection}

Primary miRNA (pri-miRNA) originate in the nucleus as single long transcripts up to 1000 nucleotides long which can be processed by the RNase III enzyme Drosha and the RNA binding protein DGCR8 into pre-cursor hairpin structures $~ 70-100$ nt long termed "pre-miRNA" [13-15]. Transport to the cytoplasm is via Exportin 5 where the pre-miRNA is further processed by Dicer into a miRNA duplex consisting of the mature miRNA and the so called miRNA* strand (which is generally degraded) [16]. Incorporation of the mature miRNA into a miRNA-induced silencing complex (miRISC) is facilitated by Argonate protein involvement and transport to the target mRNA has recently been reported to involve importin 8 [17] 
(Figure 1). Single miRNA can exist in introns and exons of so called host genes, whilst certain groups of miRNAs are present in clusters in the genome for example the miR-17-92 family. Within each miRNA there exists a 2-8 nucleotide "seed region" thought to be critical for target selection [18]. Mature miRNAs use this seed region to bind selectively to miRNA recognition elements (MRE) within the 3' untranslated region (3'UTR) of target mRNAs. Different target genes may contain several MREs and therefore be regulated by numerous miRNAs. The number of and distance between MREs are considered important for the biological activity of miRNAs. Targeting and subsequent repression of transcripts may also occur at the 5'UTR with equal efficacy [19]. However, the majority of studies have revolved around determination of miRNA:mRNA interactions at the 3'UTR.

\section{miRNA regulation}

The matter of miRNA regulation and expression has been subject to much speculation with multiple levels of control being identified in recent studies. O'Connell et al describe three levels of control, namely at the stages of "(i) transcription, (ii) processing and (iii) subcellular localisation" [20]. Stage (i) includes induction of miRNA expression by transcription factors in response to inflammatory stimuli and cellular stresses, stage (ii) impaired processing may be due to dicer inhibition [21] or post-transcriptional modifications [22] and finally stage (iii) is where miRNA can localise to stress granules and p-bodies; a process which is poorly understood at this time. Epigenetic mechanisms controlling miRNA expression have been described whereby down-regulation of miR-126 for example can be induced by inhibitors of DNA methylation and histone deacetylation [23]. Alterations in miRNA function can also occur as a result of single nucleotide polymorphisms (SNPs). Tan et al reported compromised binding of miR-148a, $-148 \mathrm{~b}$ and -152 to the asthma susceptibility gene HLA-G due to the presence of a polymorphism in the 3'UTR [24].

\section{Regulatory elements}

\section{Transcription factors}

\section{Epigenetic regulation}

\section{Environmental influences}

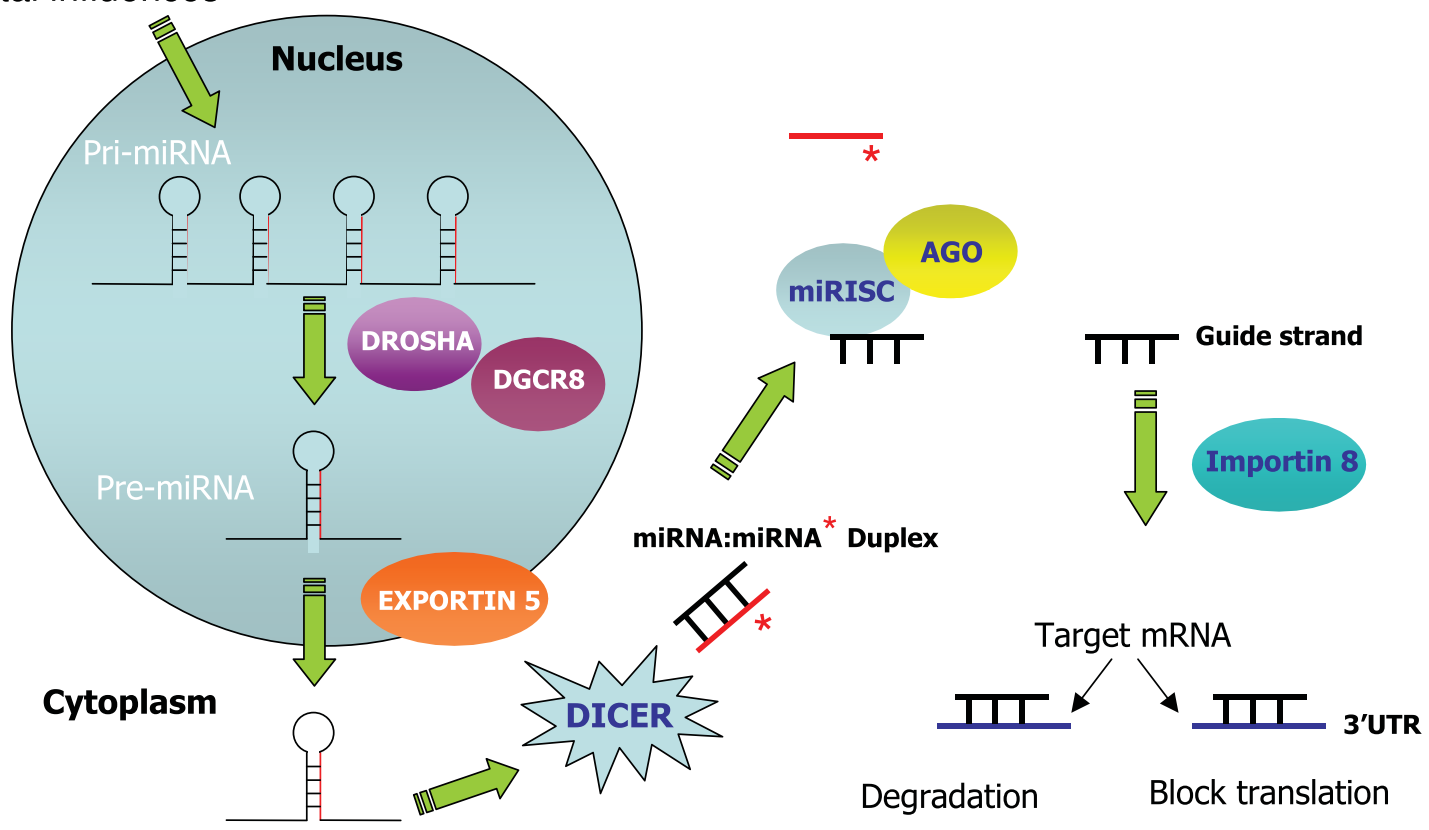

Figure 1 Representation of miRNA induction and biogenesis. Induction of miRNA expression occurs via transcription factors and other regulatory influences. Primary miRNA transcripts (pri-miRNA) produced in the nucleus are generally processed by Drosha and DGCR8 into premiRNA hairpin structures and transported to the cytoplasm by Exportin 5. The pre-miRNA is processed by Dicer into a miRNA duplex where the mature miRNA guide strand is incorporated into a miRNA-induced silencing complex (miRISC) and the miRNA* strand is degraded. Incorporation into miRISC is facilitated by AGO proteins. Importin 8 aids subsequent transport of the miRNA to the target mRNA where binding to the $3^{\prime} U T R$ occurs resulting in translational repression or degradation. 
The majority of miRNA-induced changes in gene expression are subtle exerting a modest 2-3 fold repression of targets which can hamper elucidation of miRNA function [25]. However, the most important miRNAregulated effects appear to occur as a result of miRNA down-regulation or deletion. For example, miR-126 was shown to be essential for maintenance of vascular integrity and angiogenesis in vivo whereby targeted deletion (mice) or knockdown (zebrafish) resulted in partial embryonic lethality or leaky vessels and haemorrhaging, respectively [26,27]. MiR-126 and miR-335 are specifically lost as breast cancer cells move towards metastasis and consequently these miRNAs have been suggested to function as metastasis suppressor miRNAs in human breast cancer. Their re-introduction into breast cancer cells in vivo led to reduced tumor growth, proliferation and inhibition of invasion [28]. It is also evident that changes in gene expression in one cell type may not occur in another, as illustrated in zebrafish by Mishima et al [29], where miR-430 repression of a subset of target genes in somatic cells had no effect on the same genes in primordial germ cells. This supports evidence for cell specific miRNA participation in different pathways and also draws attention to the regulation of miRNA by multiple mechanisms. One such miRNA regulatory mechanism recently described opens a potentially vast area of study whereby previously ignored "Junk" pseudogenes may act as decoys for miRNA thereby preserving expression of their functionally relevant counterpart. Poliseno et al reported that the pesudogene PTENP1 of tumor suppressor PTEN, presents a conserved region in its 3'UTR to which miRNA bind, leading to de-repression of PTEN and enhanced tumor suppressor activity [30]. Recent work in C.elegans and plants have uncovered proteins that regulate miRNA turnover $[31,32]$, however this has not yet been demonstrated in mammals.

\section{miRNA - immune response and TLR signalling Acquired immunity}

This arm of the immune response mediated by $\mathrm{T}$ and $\mathrm{B}$ lymphocytes is probably one of the best characterised developmental systems in mammals. Many investigators have described an integral role for miRNA in acquired immunity and these studies have been extensively reviewed [20,33-36]. The importance of miRNA in both $\mathrm{T}$ and $\mathrm{B}$ cell development has been demonstrated via disruption of miRNA processing machinery. For example, $\mathrm{T}$-cell specific deletion of dicer results in reduced $\mathrm{T}$ cell numbers and a progression towards autoimmune pathology [37] and in B-cells dicer knockout impairs pro- to pre-B cell progression almost completely accompanied by increased level of the pro apoptotic protein Bim [38]. MiR-150 has been reported to block production of mature B cells [39] via dysregulation of transcription factor C-myb which elicits critical control during multiple steps of lymphocyte differentiation [40]. Over-expression of miR-181 causes a marked in increase in B cells numbers with no effect on T cells or myeloid cells [41] and can regulate sensitivity of $\mathrm{T}$ cell receptor signalling to antigens [42]. The importance of miR-155 in maintenance of a normal immune response was highlighted by Rodriguez et al who observed that mice deficient in miR155 display diminished $\mathrm{B}$ and $\mathrm{T}$ cell responses and favored differentiation of helper $\mathrm{T}\left(\mathrm{T}_{\mathrm{H}}\right)$ cells towards a $\mathrm{T}_{\mathrm{H}} 2$ response [43].

\section{Innate immunity}

The innate immune response is a complex, highly organised first line of host defense initiated upon exposure to invading pathogens and allergens. Carefully balanced resolution of inflammation triggered by infection is critical to the prevention of chronic disease states. In the airways cellular components such as alveolar macrophages, neutrophils and epithelial cells have key functions in this process [44]. Once thought to be a non-specific response to keep infection at bay while the adaptive immune system prepared appropriately it is now known to be a prerequisite for initiation of several adaptive immune response components. Toll like receptors (TLRs) are a family of pattern recognition receptors that play an essential role in innate immunity by responding to microbial antigens such as lipopolysaccharide (LPS) and initiating signalling cascades that culminate in proinflammatory gene expression, principally via activation of the transcription factors NFkB and the IRFs [45-47]. However, whilst crucial for pathogen clearance, under or over-exuberant TLR signalling can be deleterious to the host leading to the pathogenesis of chronic inflammatory conditions $[48,49]$. In the lung TLRs are expressed by immune cells and also epithelial cells [50]. A number of reports have provided evidence of miRNA involvement in immune cell development and in regulation of the innate immune response in part via establishment of a link between TLR signalling, miRNA expression and activation of inflammatory pathways [33-36,51-53]. Both bacterial and viral ligands of the TLRs can induce the expression of several miRNA as can inflammatory cytokines produced as a direct result of TLR stimulation.

\section{LPS/TLR4 signalling}

Of the TLRs characterised to date, TLR4 in particular has been the subject of the majority of studies where a firm link between miRNA expression and TLR4 signalling pathways is now recognised, (depicted in Figure 2). The vast majority of studies have been performed in macrophages (murine and human, in vitro and in vivo) and to a lesser extent, neutrophils, PBMCs and epithelial cells. LPS, one of the major ligands for TLR4 has been associated with induction of several miRNA including 


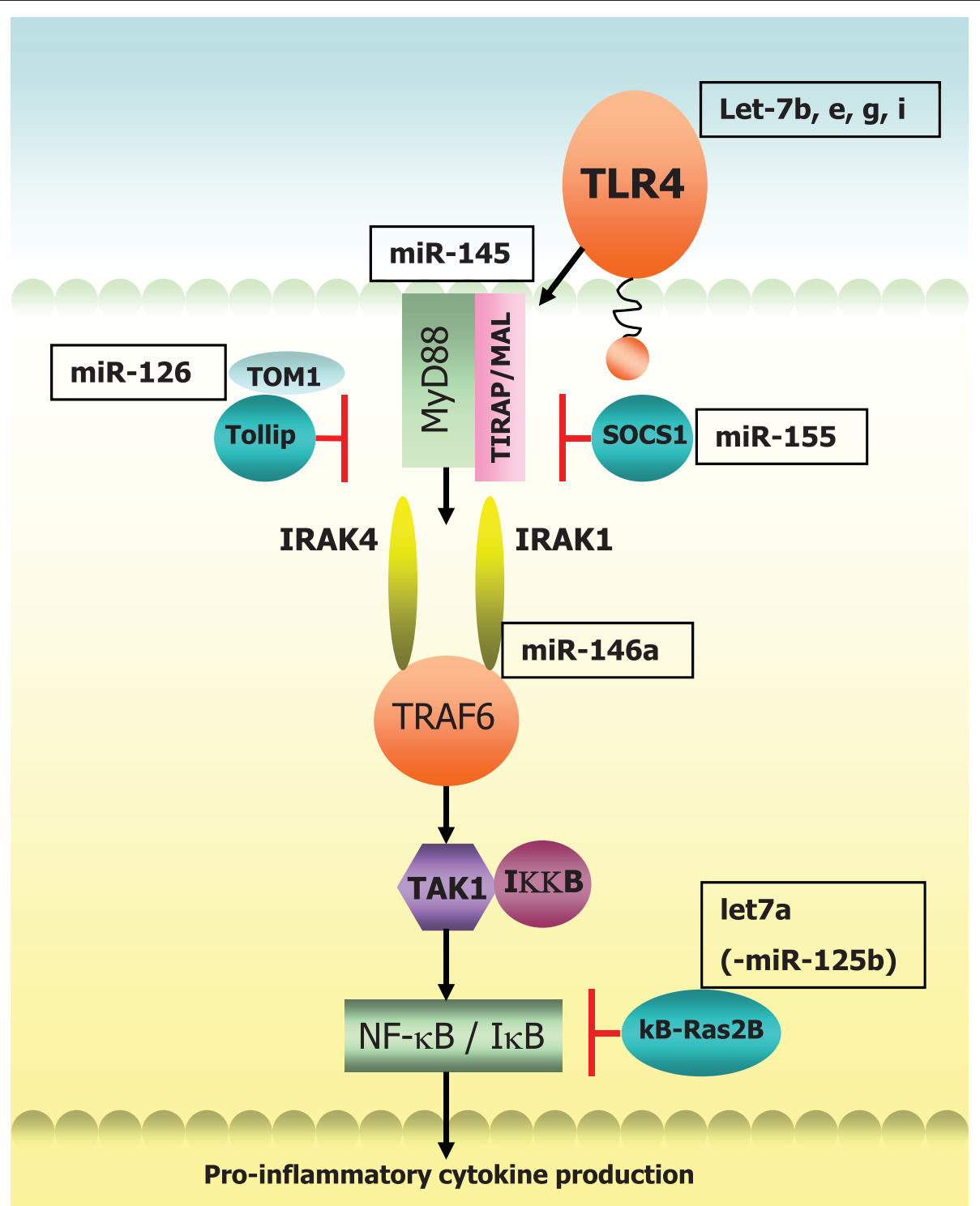

Figure 2 Selection of miRNA implicated in the TLR4 signalling pathway. TLR4 signals via MyD88 and TIRAP/MAL to IRAKs 1 and 4 . The TOM1/Tollip complex and SOCS1 are negative regulators of this pathway. The signal is transduced via TRAF6, TAK1 and IKK leading to activation of NF- $\kappa$ B via dissociation of $\mid \kappa B$. $\kappa$ B-Ras2B is an $I \kappa B$ inhibitor. miRNA targeting components of TLR4 signalling are shown in boxes. MiR-145 [126].

miR-155, -146, -9 and -21 to name a few, which were shown to target SHIP1, IRAK1/TRAF6, NF- $\kappa$ B1, and tumor suppressor PDCD4 respectively [54-57]. Expression of miR-155 can also be induced by additional TLR ligands and a plethora of pro-inflammatory cytokines [53] and in the context of inflammatory lung disease mice deficient in miR-155 display immunodeficiency and substantial airway remodelling [43]. Notably, the position of the Bic/miR-155 gene in humans is located on chromosome $21 \mathrm{q} 21$ mapping to a region of asthma and pollen sensitivity $[58,59]$. Up-regulation of miR-9 expression shown to occur upon treatment with TLR2, 4, 7 and 8 agonists, IL-1 $\beta$ and TNF- $\alpha$ but not IFN $\gamma$ was the only miRNA found to be differentially expressed in both human neutrophils and monocytes following stimulation with LPS [54].

Direct regulation of TLR4 by let-7i in human bilary epithelial cells was reported by Chen et al who showed that in the presence of LPS, let-7i expression is reduced in a MyD88/NF- $\kappa$ B dependent manner accompanied by a concomitant increase in TLR4 protein. Two other members of the let- 7 family detected in these cells (let-7b and let-7g) are also predicted to target TLR4 [60]. Contrary to this, let-7a has been shown to be induced following LPS stimulation in primary human macrophages [61]. The same study demonstrated an LPS-induced decrease in 
miR-125b whereby the net effect of LPS regulation of these miRNA resulted in inhibition of $\kappa \mathrm{B}$-Ras2, an inhibitor of $\mathrm{I} \kappa \mathrm{B}$. Pre-treatment with $17 \beta$ Estradiol abrogated the effects of LPS and was shown to suppress NF- $\kappa$ B activation through induction of $\kappa \mathrm{B}$-Ras2 via regulation of let-7a and miR125b, suggesting estrogen mediated regulation of miRNAs may be an important factor in control of inflammation [61]. Let-7a induction was observed to be NF- $\kappa \mathrm{B}$ dependent whereas the LPS-induced decrease in miR$125 \mathrm{~b}$ expression was independent of this pathway. Supporting these findings Androlidaki et al reported that LPS suppression of miR-125b is dependent on Akt signalling in murine macrophages both in vitro and in vivo [62].

\section{Negative feedback control of inflammation}

Various means of intracellular and extracellular negative control of inflammation for the maintenance of a balanced response to TLR signalling exist. Endogenously, these include decoy molecules that compete for binding to TLRs such as soluble TLRs (sTLRs) [63] and a broad spectrum of intracellular molecules ranging from nuclear receptors to proteases, kinases, transmembrane proteins, ubiquitin-modifying and adaptor proteins [64]. Emerging data on the role of miRNA in the immune response indicates that their induction and regulation may play an important role in the termination of inappropriate signalling. For example TNF- $\alpha$ mediated induction of miR-31 and miR-17-3p target endothelial adhesion molecules Eselectin and ICAM-1 respectively, which are both induced by TNF- $\alpha$ thereby providing negative feedback control of inflammation [65]. Another recent study to examine the effects of IL-10 (a potent anti-inflammatory cytokine poorly expressed in asthma) on TLR4 signalling demonstrates that IL-10 can suppress LPS-induced miR-155 expression in a STAT3-dependent manner leading to an increase in SHIP1 in bone marrow derived cells and in human PBMCs. LPS is known to induce IL-10 and negatively impact on this pathway by switching off the inflammatory response, so again this suggests a feedback loop whereby induction of IL-10, promoted by LPS, keeps LPSinduced miR155 expression in check. IL-10 was found to have no effect on two other LPS induced miRNA - miR146a and miR-21 [66].

A role for miR-146 in "fine tuning" of the innate immune response was described by Taganov et al when they found that LPS-induced increased expression of miR-146a was driven by NF- $\kappa$ B in the monocytic cell line THP-1 and negatively regulates IRAK1 and TRAF6, two key adaptor molecules downstream of TLR and IL-1R signalling, again illustrating a negative feedback control loop [57]. Increased expression of miR-146a was also induced upon treatment with TNF- $\alpha$ and IL-1 $\beta$ to a lesser extent and stimulation with other TLR ligands revealed up-regulation in response to TLR2 and TLR5 activation but not by TLR3, 7 and 9 ligands [57]. In human alveolar epithelial cells stimulation with IL-1 $\beta$ elicited a rapid increase in miR-146a expression and to a lesser degree miR-146b, corresponding to a decrease in the expression of pro-inflammatory chemokines IL-8 and RANTES, which the authors again propose as negative feedback control of inflammation. Incidentally neither IL-8 nor RANTES are predicted to contain binding sites for miR-146a. Examination of miR-146 expression in primary bronchial epithelial cells revealed a comparable increase in IL-1 $\beta$-induced levels of miR-146a however miR-146b was not detected in these cells [67].

\section{miRNA and inflammatory lung disease} miRNA in lung cancer - utility as prognostic tools

Lung cancer is the leading cause of cancer-related deaths worldwide and to date the role of miRNA in lung cancer has been studied and reviewed extensively in comparison to the other lung diseases. Lung cancer can be broadly classified into small cell (SCLC) and non-small cell lung cancer (NSCLC), the latter being more common can be sub-classified into squamous and adenocarcinoma. Approximately $15-20 \%$ of human cancers are heavily associated with inflammation [68] where the involvement of NF- $\kappa$ B activation has been well documented [69]. Briefly, many miRNA identified as either tumor suppressors or oncogenes in lung cancer are also reported to be involved in the immune response, for example the let-7 family and the miR-17-92 cluster, respectively. Reduced expression of the let-7 family members in human lung cancer has been correlated with poor survival [70] and delivery of exogenous let-7 to a mouse model of NSCLC resulted in reduction of tumor load supporting a role for this miRNA as a tumor suppressor [71]. The miR-17-92 cluster over-expressed in B cell lymphomas [72,73] was found to be markedly increased in lung cancer by Hayashita et al in particular in those with SCLC histology [74] and thus has been classified as an onco-miR. Downregulation of miR-126, also a proposed tumor suppressor correlated with reciprocal expression of vascular endothelial growth factor (VEGF) in eight lung cancer cell lines and was shown to reduce tumor growth in a xenograft mouse model [75].

With the detection of miRNA in blood cells and serum as well as in tissue their value as potential diagnostic and prognostic tools in cancer is emerging. Already in a study of individuals with NSCLC, a five miRNA signature (consisting of 2 protective miRNA - miR-221 and let-7a and 3 associated with poor prognosis miR-137, -372 and $-182 \%$ ) has been identified for prediction of treatment outcome [76]. MiRNA have demonstrated remarkable stability in sputum where a combination of miR-21, $-486,-375$ and -200b were shown to distinguish lung adenocarcinoma from normal subjects with $>80$ and $90 \%$ sensitivity and specificity respectively [77] and in serum where high 
levels of miR-141 discriminated individuals with prostate cancer compared to controls [78]. Classification of lung squamous cell carcinoma versus adenocarcinoma was also reported based purely on detection of high levels of miR-205 found in the former which are not present in the latter [79].

\section{Chronic obstructive pulmonary disease (COPD)}

COPD is a disease predominantly induced by cigarette smoking and/or chronic exposure to irritants. Emphysematous lung disease in alpha-1 antitrypsin ( $\alpha 1-\mathrm{AT})$ deficient individuals can also come under this heading. Hallmarks of COPD include a progressive obstruction of the airflow, chronic inflammation in the lungs, shortness of breath, chronic cough and phlegm production [80,81]. COPD is classified as the $4^{\text {th }}$ leading cause of death in the US currently and is predicted to increase to $3^{\text {rd }}$ place by 2020 [82]. Both chronic inflammation in the airway and systemic inflammation (potentially resulting from an excess of pro-inflammatory mediators entering systemic circulation) have been attributed to the pathogenesis of COPD [83]. In particular, during exacerbations elevated levels of numerous inflammatory markers such as interleukin 6 (IL-6), IL-8, TNF- $\alpha$ and circulating activated neutrophils have been reported [83]. These high levels of primed neutrophils correlate with increased oxidative stress and the severity of exacerbation [84].

The expression of miRNA in mouse and rat lungs exposed to cigarette smoke extract (CSE) has been studied by Izotti et al $[85,86]$ where down-regulation of miRNA was observed predominantly in both models. Out of 484 miRNA analysed, 126 were down-regulated by at least 2 -fold and $24 \geq 3$-fold in smoke exposed rats, with 15 down-regulated in mice compared to just one and none up-regulated in the same animals. This is consistent with the results of miRNA expression profiling in human bronchial epithelium of 10 smokers versus 9 never smokers [87]. Twenty three miRNA were significantly down-regulated and only 5 up-regulated out of a total of 467 analysed in the smokers [87]. In silico analysis of miRNA altered in mice exposed to CSE linked their biological roles to a variety of functions including development of airway epithelial cells, stress responses, formation of pulmonary surfactant and inflammation [86]. Many miRNA involved in activation of the NF- $\kappa \mathrm{B}$ pathway such as miR-30, miR-146, miR-132 and miR-155 were down-regulated by CSE in rodents [86]. Contrary to the CSE studies primary human bronchial epithelial cells exposed to diesel exhaust particles (DEP) exhibited a predominant up-regulation $(\mathrm{n}=130)$ compared to downregulation $(n=67)$ of miRNAs. Like cigarette smoke, DEP has been linked to pulmonary inflammation, increased risk of cancer and exacerbations in asthma and COPD [88]. Bioinformatic analysis to determine the biological relevance of miRNA altered by DEP exposure generated molecular networks enriched for inflammatory pathways which correlated to IL-8, NF- $\kappa$ B and CXCR4 signalling pathways. MiR-494 (increased $\geq 1.5$ fold upon DEP exposure) was predicted to have important roles in $\mathrm{NF}-\kappa \mathrm{B}$ and virus activated signalling [88].

\section{Asthma}

Asthma is a widespread complex disease affecting approximately 300 million people worldwide [89]. Its pathogenesis can be attributed to both genetic factors and exposure to environmental triggers at various stages of development ranging from pre-natal maternal exposure to allergens through to occupational exposure in adulthood for example [90]. Asthma is characterised by chronic inflammation caused by persistent infiltration of eosinophils and mast cells, an abnormal T helper-2 $\left(\mathrm{T}_{\mathrm{H}} 2\right)$ response and the downstream actions of their secreted cytokines. The $\mathrm{T}_{\mathrm{H}} 2$ cytokines IL-4, 5, 9 and 13 have all been linked to airway hyper-responsiveness (AHR), mucus hypersecretion, eosinophil infiltration and elevated levels of IgE [91,92]. Structural changes leading to airway remodelling combined with chronic inflammation give rise to its hallmarks - reversible AHR and airway obstruction [93].

Focus on the role of miRNA in asthma has increased recently with a number of studies in the past year reporting differential expression of miRNA in various models of asthma. In a study of 579 miRNAs in bitransgenic mice expressing IL-13 (a key $\mathrm{T}_{\mathrm{H}} 2$ derived cytokine) in a lung specific manner, 21 were differentially expressed upon induction of experimental asthma following treatment with doxycycline [94]. The most up-regulated miRNA was miR-21, with miR-1 being the most downregulated. These observations were replicated in two other separate mouse models of experimental asthma [94]. All three asthma models shared similar phenotypes including AHR, mucus production and $\mathrm{T}_{\mathrm{H}} 2$ eosinophilic inflammation and highest expression levels of miR-21 were observed in macrophages and dendritic cells. Independently, Lu et al showed IL-4 transgenic mice demonstrated increased expression of miR-21. IL-13-induced expression of miR-21 was shown to be dependent on the receptor IL-13R $\alpha 1$, with allergen induced expression mostly independent of this receptor. Up-regulation of miR-21 correlated with down-regulation of its predicted target IL-12p35 which was confirmed as a molecular target using a luciferase reporter system. Interestingly IL-12 derived from macrophages and dendritic cells is involved in $\mathrm{T}_{\mathrm{H}} 1$ polarisation in the adaptive immune response $[95,96]$, suggesting that miR-21 may potentially regulate a number of processes involved in allergic airway inflammation [94]. Another study featuring IL-13 influences on miRNA expression was performed by Chiba et al [97]. The monomeric GTP-binding protein RhoA has been associated with contraction of smooth muscle, whereby 
its over-expression in an animal model of allergic bronchial asthma augmented contraction of bronchial smooth muscle $[98,99]$. RhoA over-expression correlated with down-regulation of miR-133a in human bronchial smooth muscle cells (hBSM) treated with IL-13 and in bronchial tissue from sensitised BALB/c mice repeatedly challenged with ovalbumin [97]. This data suggests that IL-13, one of the major up-regulated cytokines in asthmatic airways, may play a role in AHR induction in part through repression of miR-133a and inducing increased expression of RhoA [97].

Surprisingly, expression profiling of 227 miRNA in airway biopsies from mild asthmatics before and after treatment with the inhaled corticosteroid budesonide and also compared to healthy non-asthmatics revealed no differences in miRNA expression [100]. However, analysis of a range of cell types found within human lung (isolated from a 5 donor pool) including macrophages, airway smooth muscle cells, epithelial cells and fibroblasts demonstrated miRNA profiles specific to particular cell types. The majority of highly expressed miRNA were contained within alveolar macrophages compared to other cell types, in particular miRs -30a-5p, -92, -142-3p, $-146 \mathrm{~b},-191,-223,-320$ and -342 . In order to explain this, the authors proposed that differential miRNA expression may occur in mild asthmatics possibly within specific cells types which could have been masked in the airway biopsies tested due to the presence of multiple cell types. Potentially in more severe cases of asthma, differential miRNA expression might be more evident [100]. Cystic fibrosis (CF)

$\mathrm{CF}$ is one of the commonest lethal genetic diseases in Caucasians with approximate incidences of 1:3500 in Europe and North America. CF is also evident in African and Asian populations albeit to a much lesser degree (1:5000 - 1:20,000) [101]. Despite significant advances in treatment regimes CF remains a condition for which there is no effective cure with $>90 \%$ of deaths occurring as a result of respiratory failure [102]. Following establishment of CF as a disease with altered chloride ion transport the gene responsible for the cause of CF (CF transmembrane conductance regulator - CFTR) was discovered in 1989 [103,104]. There have been over 1400 disease-causing mutations identified to date in the CFTR gene and these can be generally grouped into six classes based on cellular phenotype [105]. $\Delta 508$ which falls into class II is the most prevalent mutation worldwide [106].

CF lung disease is characterised by chronic infection, exaggerated intra-pulmonary protease levels e.g. neutrophil elastase (NE) and neutrophil dominated airway inflammation. Impaired chloride ion channel secretion results in a build up of thick sticky mucus and reduced mucocilary clearance leading to bacterial colonisation with bacteria such as Pseudomonas aeruginosa. The gram-negative bacterial cell wall component LPS and IL-1 $\beta$, which bind to Toll-Like Receptor 4 (TLR4) and the IL-1 Type-I receptor (IL-1RI), respectively, play a pivotal role in this process. These agonists can activate the innate immune response culminating in pro-inflammatory gene expression leading to infiltration of large numbers of neutrophils contributing to sustained endobronchial inflammation and tissue damage in the CF lung. In the context of CF airway epithelial cells both the IL-1RI and TLRs have been shown to promote proinflammatory gene transcription following stimulation with their cognate agonists $[107,108]$. For example, in airway epithelial cells of non-CF and CF origin triacylated lipopeptide, LPS or unmethylated CpG DNA can induce IL-6, IL- 8 and TNF- $\alpha$ production via TLRs 2,4 and 9 [107]. Similarly, IL-1 $\beta$ can up-regulate production of a plethora of pro-inflammatory cytokines [108]. Thus IL-1RI and/or TLRs and their signalling intermediates represent potential therapeutic targets for CF. Accumulation of neutrophils with impaired function, their subsequent degradation and release of intracellular contents including NE contributes greatly to sustained proteaseantiprotease imbalance [109] and damage to structural, cellular and soluble components of the CF lung [110]. NE has also been shown to induce IL- 8 expression via MyD88/IRAK/TRAF6 pathways in human bronchial epithelium [111].

We have previously reported differential expression of miRNA in CF whereby expression profiling of 667 different human miRNAs was performed on bronchial brushings taken from CF and non-CF individuals ( $\mathrm{n}=5$ each) by qRT-PCR, [112]. Expression of 391 miRNAs was detected across all samples with 56 being downregulated (Relative Quantification $(\mathrm{RQ}) \leq 0.7$ ) and 36 up-regulated $(R Q \geq 1.5)$ in $C F$ versus non CF controls. Expression of miR-218 remained unchanged in the bronchial epithelium of CF versus non-CF individuals [112], however it was found to be the most significantly down-regulated miRNA in bronchial epithelial cells of smokers vs. non- smokers in a study by Shembri et al [87] providing support of the phenomenon of diseasespecific expression of miRNA. Consistent with a report of miR-494 up-regulation in bronchial epithelial cells exposed to DEP [88] we also found this miRNA to be up-regulated in CF versus non-CF bronchial brushings [112]. MiR-126, discussed in the following section, was found to be significantly decreased in four of the five CF samples compared to controls. We are currently pursuing the role of a selection of miRNA and their predicted biological targets resulting from follow-up in silico analysis, with a view to uncovering previously unidentified regulatory mechanisms that may control changes in gene expression and direct the development of future 
therapeutic strategies, possibly directed at IL-1RI/TLR signalling, for this debilitating and fatal disorder.

miR-126 in CF and asthma - a key innate immune regulator?

MiR-126 is 21 nucleotides in length, located on chromosome 9q34.3 and is contained within intron 5 of its host gene epidermal growth factor like-7 (EGFL-7) [113]. It has previously been shown to have functional roles in angiogenesis [26,27], to be down-regulated in a number of malignancies $[23,114]$ and to act as a tumor suppressor in breast cancer [28]. We selected miR-126 for further investigation following miRNA expression profiling in CF vs. non-CF bronchial brushings given that its expression is known to be highest in vascularised tissues such as the lung, heart and kidney [113,115,116] and as it has been shown to be present in bronchial epithelium [114]. We found down-regulation of miR-126 in CF bronchial epithelial cells correlated with a significant up-regulation of TOM1 mRNA when compared to their non-CF counterparts. TOM1 (target of Myb1) has been shown to interact with Toll interacting protein (Tollip), forming a complex to regulate endosomal trafficking of ubiquitinated proteins. TOM1 has also been proposed as a negative regulator of IL- $1 \beta$ and TNF- $\alpha$ induced signalling pathways [117-119]. Over-expression of miR-126 decreased TOM1 protein production in CF bronchial epithelial cells and decreased luciferase activity in a reporter gene containing the full length 3'UTR of TOM1 demonstrating direct targeting. Following stimulation with LPS or IL-1 $\beta$, over-expression of TOM1 was found to down-regulate NF- $\kappa \mathrm{B}$ luciferase activity. Conversely, TOM1 knockdown resulted in a significant increase in NF- $\kappa \mathrm{B}$ regulated IL- 8 secretion suggesting that miR-126 may have an important role in regulating innate immune responses in the CF lung.

Neither LPS nor IL-1 $\beta$ alone had any effect on miR126 expression and similarly Harris et al showed miR126 was not altered in response to TNF- $\alpha$ [113]. They reported miR-126 inhibits vascular cell adhesion molecule 1 (VCAM1) in vitro and proposed a regulatory role for miR-126 in inflammation, specifically in the vasculature. A role for miR-126 in the pathogenesis of allergic asthma was described by Mattes et al who showed increased expression levels of miR-16, -21 and -126 in the lower airway tissue isolated from a BALB/c mouse model of allergic asthma induced by house dust mite (HDM) challenge. Inhibition of miR-126 resulted in abrogation of the asthmatic phenotype as demonstrated by a reduction in AHR, inflammation, $\mathrm{T}_{\mathrm{H}} 2$ responses, mucus hypersecretion and eosinophil recruitment. They concluded that miR-126 expression is dependent on both the TLR4 and MyD88 pathways as they failed to detect its up-regulation in the airways of either TLR4 or MyD88 deficient mice. These mice failed to display any of the hallmark features of asthma despite repeated allergen challenge [120]. Further analysis of miR-126 inhibition in airway walls of HDM sensitised mice revealed significant up-regulation of Oct binding factor 1 (OBF.1), known to be a critical regulator of the transcription factor PU.1 which can negatively regulate $\mathrm{T}_{\mathrm{H}} 2$ responses and TLR4 expression through suppression of GATA3 [121,122]. Notably the suppression of $\mathrm{T}_{\mathrm{H}} 2$ responses occurred in the absence of a $\mathrm{T}_{\mathrm{H}} 1$ response, indicating specific targeting of the $\mathrm{T}_{\mathrm{H}} 2$ regulated inflammatory response by miR-126 in allergic lung disease [120]. Taken together with our data this supports an important role for miR-126 in the innate immune response of the lung.

\section{Idiopathic pulmonary fibrosis (IPF)}

IPF is a progressive disease of the lung interstituim characterised by epithelial cell injury, fibroblast proliferation and excessive accumulation of extracellular matrix proteins such as collagen within the lung parenchyma. This is usually accompanied by increased levels of the key fibrotic mediator transforming growth factor $\beta$ (TGF- $\beta$ ) and other cytokines produced at the site of active fibrosis [123]. Evidence of miRNA involvement in the pathogenesis of IPF is just starting to emerge with a number of recent studies describing differential miRNA expression. Pottier et al compared miRNA expression profiles of normal lung fibroblasts with alveolar epithelial cells and found a selection of miRNA were preferentially expressed in fibroblasts. Expression of miR-155 was up-regulated in the presence of TNF- $\alpha$ and IL- $\beta$ with a concomitant reduction of keratinocyte growth factor (KGF) in normal pulmonary fibroblasts leading to increased fibroblast migration via activation of caspase 3. Following treatment with TGF$\beta$, miR-155 levels were reduced. In a mouse model of fibrosis miR-155 levels correlated with the degree of fibrosis [123]. Expression profiling of human IPF lung tissue biopsies compared with controls revealed differential expression of 46 miRNA. Of those, 18 were significantly down-regulated including miR-126, miR-203, several members of the miR-30 family and let-7d. Again TGF- $\beta$ was found to decrease let- $7 \mathrm{~d}$ which correlated with an up-regulation of its predicted target HMGA2. Knock down of let-7d resulted in increased levels of collagen and alveolar septal thickening in mouse lungs in vivo and epithelial mesenchymal transition in vitro [124]. The oncogenic miR-21 was also observed to play a role in IPF whereby it was found to be up-regulated in human IPF samples and in the lungs of mice with bleomycin induced fibrosis. Enhanced miR-21 expression was observed in primary pulmonary fibroblasts treated with TGF- $\beta$. Inhibition of miR-21 decreased the severity of fibrosis whereas over-expression promoted TGF- $\beta$ induced fibrotic activity [125]. 


\section{Conclusion}

Intensive research over the past decade has rapidly advanced our knowledge of miRNA participation in numerous biological processes and disease states. It is clear that both appropriate miRNA regulation and inappropriate dysregulation forms a major part of mammalian development and disease progression respectively. In the early stages of miRNA discovery it was predicted that they could potentially regulate up to one third of the human genome which is probably largely underestimated with some target prediction databases suggesting thousands of potential targets for certain miRNA. One single miRNA has the capacity to regulate hundreds of targets and likewise individual target genes may be regulated by several miRNA depending on the amount of MREs they possess. Questions remain as to whether preferential binding of certain miRNA occurs, i.e. are some miRNA more dominant than others? A number of profiling studies have reported that the majority of differentially expressed miRNA in disease states are down-regulated [85-87]. We observed this to be the case in CF where almost twice as many miRNA were down-regulated compared to up-regulated versus non-CF controls. Upon in silico analysis for a number of target genes of particular interest to our laboratory we found several predicted to be regulated by an equal number of both up- and down regulated miRNA, suggesting possible maintenance of a balance of gene expression.

In summary, we have outlined some of the evidence identifying miRNA as key regulators of the innate immune response with particular reference to TLR4 signalling and negative feedback control of inflammation where both miRNA and transcription factors can regulate one another to maintain a stable cellular environment and whereby irregular expression can contribute to inflammatory disease progression. We discuss miRNA involvement in lung cancer and also describe the emerging role of miRNA in the progression of inflammatory lung diseases such as CF, COPD, asthma and IPF. The dysregulation of miRNA in chronic inflammatory lung disease represents an exciting possibility for therapeutic intervention however the development of strategies harnessing miRNA expression for treatment of these diseases is at an early stage and will take some time to optimise delivery, stability and specificity. Targeting miRNA expression in the lung may represent a realistic therapeutic intervention as aerosolisation enhances drug delivery to the site of action and decreases systemic exposure of the patient to the therapy, thereby reducing offtarget effects. However the nucleic acid-based molecules used for miRNA modulation are large negatively charged moieties and these physicochemical properties limits intracellular delivery to their sites of action. In the meantime several challenges remain for investigators to fully elucidate the functional relevance of miRNA: mRNA interactions, to assess the impact of target gene regulation by several miRNA to establish if preferential binding/synergistic repression exists and also to establish the mechanism for clearance of miRNA from the cell, all of which will help define miRNA regulation in complex cellular systems and facilitate the development of specific therapeutic approaches.

\section{Acknowledgements}

Funding for work in this laboratory is gratefully acknowledged from Science Foundation Ireland, the Health Research Board of Ireland and Medical Research Charities Group, U.S. Alpha One Foundation.

\section{Authors' contributions}

IKO and CMG drafted and revised the manuscript. IKO, NMCE and CMG read and approved the final article.

\section{Competing interests}

The authors declare that they have no competing interests.

Received: 21 July 2010 Accepted: 28 October 2010

Published: 28 October 2010

\section{References}

1. Hao S, Baltimore D: The stability of mRNA influences the temporal order of the induction of genes encoding inflammatory molecules. Nat Immunol 2009, 10(3):281-288.

2. McCall CE, Yoza BK: Gene silencing in severe systemic inflammation. Am J Respir Crit Care Med 2007, 175(8):763-767.

3. Britten RJ, Davidson EH: Gene regulation for higher cells: a theory. Science 1969, 165(891):349-357.

4. Lee RC, Feinbaum RL, Ambros V: The C. elegans heterochronic gene lin-4 encodes small RNAs with antisense complementarity to lin-14. Cell 1993, 75(5):843-854.

5. Lee RC, Ambros V: An extensive class of small RNAs in Caenorhabditis elegans. Science 2001, 294(5543):862-864.

6. Lau NC, Lim LP, Weinstein EG, Bartel DP: An abundant class of tiny RNAs with probable regulatory roles in Caenorhabditis elegans. Science 2001, 294(5543):858-862.

7. Reinhart BJ, Weinstein EG, Rhoades MW, Bartel B, Bartel DP: MicroRNAs in plants. Genes Dev 2002, 16(13):1616-1626.

8. Calin GA, Dumitru CD, Shimizu M, Bichi R, Zupo S, Noch E, Aldler H, Rattan S, Keating M, Rai K, Rassenti L, Kipps T, Negrini M, Bullrich F, Croce CM: Frequent deletions and down-regulation of micro- RNA genes miR15 and miR16 at 13q14 in chronic lymphocytic leukemia. Proc Natl Acad Sci USA 2002, 99(24):15524-15529.

9. Fabbri M, Garzon R, Cimmino A, Liu Z, Zanesi N, Callegari E, Liu S, Alder H, Costinean S, Fernandez-Cymering C, Volinia S, Guler G, Morrison CD, Chan KK, Marcucci G, Calin GA, Huebner K, Croce CM: MicroRNA- 29 family reverts aberrant methylation in lung cancer by targeting DNA methyltransferases 3A and 3B. Proc Natl Acad Sci USA 2007, 104(40):15805-15810.

10. Mertens-Talcott SU, Chintharlapalli S, Li X, Safe S: The oncogenic microRNA-27a targets genes that regulate specificity protein transcription factors and the G2-M checkpoint in MDA-MB-231 breast cancer cells. Cancer Res 2007, 67(22):11001-11011.

11. Vasudevan $S$, Tong $Y$, Steitz JA: Switching from repression to activation: microRNAs can up-regulate translation. Science 2007, 318(5858):1931-1934.

12. Grosshans H, Filipowicz W: Molecular biology: the expanding world of small RNAs. Nature 2008, 451(7177):414-416.

13. Denli AM, Tops BB, Plasterk RH, Ketting RF, Hannon GJ: Processing of primary microRNAs by the Microprocessor complex. Nature 2004, 432(7014):231-235 
14. Han J, Lee Y, Yeom KH, Kim YK, Jin H, Kim VN: The Drosha-DGCR8 complex in primary microRNA processing. Genes Dev 2004, 18(24):3016-3027.

15. Lee Y, Kim M, Han J, Yeom KH, Lee S, Baek SH, Kim VN: MicroRNA genes are transcribed by RNA polymerase II. EMBO J 2004, 23(20):4051-4060.

16. Kim VN: MicroRNA biogenesis: coordinated cropping and dicing. Nat ReV Mol Cell Biol 2005, 6(5):376-385.

17. Weinmann L, Hock J, Ivacevic T, Ohrt T, Mutze J, Schwille P, Kremmer E Benes $V$, Urlaub H, Meister $\mathrm{G}$ : Importin 8 is a gene silencing factor that targets argonaute proteins to distinct mRNAs. Cell 2009, 136(3):496-507.

18. Liu J: Control of protein synthesis and mRNA degradation by microRNAs. Curr Opin Cell Biol 2008, 20(2):214-221.

19. Lytle JR, Yario TA, Steitz JA: Target mRNAs are repressed as efficiently by microRNA-binding sites in the $5^{\prime}$ UTR as in the $3^{\prime}$ UTR. Proc Natl Acad Sci USA 2007, 104(23):9667-9672

20. O'Connell RM, Rao DS, Chaudhuri AA, Baltimore D: Physiological and pathological roles for microRNAs in the immune system. Nat Rev Immunol 2010, 10(2):111-122.

21. Wiesen $J$ L, Tomasi TB: Dicer is regulated by cellular stresses and interferons. Mol Immunol 2009, 46(6):1222-1228.

22. Suzuki HI, Yamagata K, Sugimoto K, Iwamoto T, Kato S, Miyazono K: Modulation of microRNA processing by p53. Nature 2009, 460(7254):529-533

23. Saito Y, Friedman JM, Chihara Y, Egger G, Chuang JC, Liang G: Epigenetic therapy upregulates the tumor suppressor microRNA-126 and its host gene EGFL7 in human cancer cells. Biochem Biophys Res Commun 2009, 379(3):726-731.

24. Tan Z, Randall G, Fan J, Camoretti-Mercado B, Brockman-Schneider R, Pan L, Solway J, Gern JE, Lemanske RF, Nicolae D, Ober C: Allele-specific targeting of microRNAs to HLA-G and risk of asthma. Am J Hum Genet 2007, 81(4):829-834.

25. Takacs CM, Giraldez AJ: MicroRNAs as genetic sculptors: Fishing for clues. Semin Cell Dev Biol 2010

26. Fish JE, Santoro MM, Morton SU, Yu S, Yeh RF, Wythe JD, Ivey KN, Bruneau BG, Stainier DY, Srivastava D: miR-126 regulates angiogenic signalling and vascular integrity. Dev Cell 2008, 15(2):272-284.

27. Wang S, Aurora AB, Johnson BA, Qi X, McAnally J, Hill JA, Richardson JA, Bassel-Duby R, Olson EN: The endothelial-specific microRNA miR-126 governs vascular integrity and angiogenesis. Dev Cell 2008, 15(2):261-271.

28. Tavazoie SF, Alarcon C, Oskarsson T, Padua D, Wang Q, Bos PD, Gerald WL, Massague J: Endogenous human microRNAs that suppress breast cancer metastasis. Nature 2008, 451(7175):147-152.

29. Mishima Y, Giraldez AJ, Takeda Y, Fujiwara T, Sakamoto H, Schier AF, Inoue K: Differential regulation of germline mRNAs in soma and germ cells by zebrafish miR-430. Curr Biol 2006, 16(21):2135-2142.

30. Poliseno L, Salmena L, Zhang J, Carver B, Haveman WJ, Pandolfi PP: A coding-independent function of gene and pseudogene mRNAs regulates tumour biology. Nature 2010, 465(7301):1033-1038.

31. Chatterjee $\mathrm{S}$, Grosshans H: Active turnover modulates mature microRNA activity in Caenorhabditis elegans. Nature 2009, 461(7263):546-549.

32. Ramachandran $\mathrm{V}$, Chen $\mathrm{X}$ : Degradation of microRNAs by a family of exoribonucleases in Arabidopsis. Science 2008, 321(5895):1490-1492.

33. Baltimore D, Boldin MP, O'Connell RM, Rao DS, Taganov KD: MicroRNAs: new regulators of immune cell development and function. Nat Immunol 2008, 9(8):839-845

34. Lindsay MA: microRNAs and the immune response. Trends Immunol 2008, 29(7):343-351.

35. Nana-Sinkam SP, Hunter MG, Nuovo GJ, Schmittgen TD, Gelinas R, Galas D, Marsh CB: Integrating the MicroRNome into the study of lung disease. Am J Respir Crit Care Med 2009, 179(1):4-10.

36. Sonkoly E, Stahle M, Pivarcsi A: MicroRNAs and immunity: novel players in the regulation of normal immune function and inflammation. Semin Cancer Biol 2008, 18(2):131-140

37. Cobb BS, Nesterova TB, Thompson E, Hertweck A, O'Connor E, Godwin J, Wilson CB, Brockdorff N, Fisher AG, Smale ST, Merkenschlager M: T cell lineage choice and differentiation in the absence of the RNase III enzyme Dicer. J Exp Med 2005, 201(9):1367-1373.

38. Muljo SA, Ansel KM, Kanellopoulou C, Livingston DM, Rao A, Rajewsky K: Aberrant T cell differentiation in the absence of Dicer. J Exp Med 2005, 202(2):261-269.

39. Zhou B, Wang S, Mayr C, Bartel DP, Lodish HF: miR-150, a microRNA expressed in mature $B$ and $T$ cells, blocks early $B$ cell development when expressed prematurely. Proc Natl Acad Sci USA 2007, 104(17):7080-7085.

40. Xiao C, Calado DP, Galler G, Thai TH, Patterson HC, Wang J, Rajewsky N, Bender TP, Rajewsky K: MiR-150 controls B cell differentiation by targeting the transcription factor c-Myb. Cell 2007, 131(1):146-159.

41. Chen CZ, Li L, Lodish HF, Bartel DP: MicroRNAs modulate hematopoietic lineage differentiation. Science 2004, 303(5654):83-86

42. Li QJ, Chau J, Ebert PJ, Sylvester G, Min H, Liu G, Braich R, Manoharan M, Soutschek J, Skare P, Klein LO, Davis MM, Chen CZ: miR-181a is an intrinsic modulator of T cell sensitivity and selection. Cell 2007, 129(1):147-161.

43. Rodriguez A, Vigorito E, Clare S, Warren MV, Couttet $P$, Soond DR, van Dongen S, Grocock RJ, Das PP, Miska EA, Vetrie D, Okkenhaug K, Enright AJ, Dougan G, Turner M, Bradley A: Requirement of bic/microRNA-155 for normal immune function. Science 2007, 316(5824):608-611.

44. Brennan S: Innate immune activation and cystic fibrosis. Paediatr Respir Rev 2008, 9(4):271-279, quiz 279-280.

45. Colonna M: TLR pathways and IFN-regulatory factors: to each its own. Eur J Immunol 2007, 37(2):306-309.

46. O'Neill LA: How Toll-like receptors signal: what we know and what we don't know. Curr Opin Immunol 2006, 18(1):3-9.

47. Takeda K, Akira S: TLR signalling pathways. Semin Immunol 2004, 16(1):3-9.

48. Chotirmall SH, Greene CM, Oglesby IK, Thomas W, O'Neill SJ, Harvey BJ, McElvaney NG: 17Beta-estradiol inhibits IL-8 in cystic fibrosis by upregulating secretory leucoprotease inhibitor. Am J Respir Crit Care Med 2010, 182(1):62-72

49. Cook DN, Pisetsky DS, Schwartz DA: Toll-like receptors in the pathogenesis of human disease. Nat Immunol 2004, 5(10):975-979.

50. Sabroe I: Toll-Like receptors in respiratory disease. Mechanisms of pulmonary innate immunity Research Signpost; 2008.

51. Taganov KD, Boldin MP, Baltimore D: MicroRNAs and immunity: tiny players in a big field. Immunity 2007, 26(2):133-137.

52. Pedersen I, David M: MicroRNAs in the immune response. Cytokine 2008, 43(3):391-394

53. O'Connell RM, Taganov KD, Boldin MP, Cheng G, Baltimore D: MicroRNA155 is induced during the macrophage inflammatory response. Proc Natl Acad Sci USA 2007, 104(5):1604-1609.

54. Bazzoni F, Rossato M, Fabbri M, Gaudiosi D, Mirolo M, Mori L, Tamassia N, Mantovani A, Cassatella MA, Locati M: Induction and regulatory function of miR-9 in human monocytes and neutrophils exposed to proinflammatory signals. Proc Natl Acad Sci USA 2009, 106(13):5282-5287.

55. O'Connell RM, Chaudhuri AA, Rao DS, Baltimore D: Inositol phosphatase SHIP1 is a primary target of miR-155. Proc Natl Acad Sci USA 2009, 106(17):7113-7118.

56. Sheedy FJ, Palsson-McDermott E, Hennessy EJ, Martin C, O'Leary JJ, Ruan Q, Johnson DS, Chen Y, O'Neill LA: Negative regulation of TLR4 via targeting of the proinflammatory tumor suppressor PDCD4 by the microRNA miR21. Nat Immunol 2010, 11(2):141-147.

57. Taganov KD, Boldin MP, Chang KJ, Baltimore D: NF-kappaB-dependent induction of microRNA miR-146, an inhibitor targeted to signalling proteins of innate immune responses. Proc Natl Acad Sci USA 2006, 103(33):12481-12486.

58. Blumenthal MN, Langefeld CD, Barnes KC, Ober C, Meyers DA, King RA, Beaty TH, Beck SR, Bleecker ER, Rich SS: A genome-wide search for quantitative trait loci contributing to variation in seasonal pollen reactivity. J Allergy Clin Immunol 2006, 117(1):79-85.

59. Ober C, Cox NJ, Abney M, Di Rienzo A, Lander ES, Changyaleket B, Gidley H, Kurtz B, Lee J, Nance M, Pettersson A, Prescott J, Richardson A, Schlenker E, Summerhill E, Willadsen S, Parry R: Genome-wide search for asthma susceptibility loci in a founder population. The Collaborative Study on the Genetics of Asthma. Hum Mol Genet 1998, 7(9):1393-1398.

60. Chen XM, Splinter PL, O'Hara SP, LaRusso NF: A cellular micro-RNA, let-7i, regulates Toll-like receptor 4 expression and contributes to cholangiocyte immune responses against Cryptosporidium parvum infection. J Biol Chem 2007, 282(39):28929-28938.

61. Murphy AJ, Guyre PM, Pioli PA: Estradiol suppresses NF-kappa B activation through coordinated regulation of let-7a and miR-125b in primary human macrophages. J Immunol 2010, 184(9):5029-5037.

62. Androulidaki A, lliopoulos D, Arranz A, Doxaki C, Schworer S, Zacharioudaki V, Margioris AN, Tsichlis PN, Tsatsanis C: The kinase Akt1 controls macrophage response to lipopolysaccharide by regulating microRNAs. Immunity 2009, 31(2):220-231 
63. Liew FY, Xu D, Brint EK, O'Neill LA: Negative regulation of toll-like receptormediated immune responses. Nat Rev Immunol 2005, 5(6):446-458.

64. Greene CM, Branagan P, McElvaney NG: Toll-like receptors as therapeutic targets in cystic fibrosis. Expert Opin Ther Targets 2008, 12(12):1481-1495.

65. Suarez Y, Wang C, Manes TD, Pober JS: Cutting edge: TNF-induced microRNAs regulate TNF-induced expression of E-selectin and intercellular adhesion molecule-1 on human endothelial cells: feedback control of inflammation. J Immunol 2010, 184(1):21-25.

66. McCoy CE, Sheedy FJ, Qualls JE, Doyle SL, Quinn SR, Murray PJ, O'Neill LA: IL-10 inhibits miR-155 induction by toll-like receptors. J Biol Chem 2010, 285(27):20492-20498

67. Perry MM, Moschos SA, Williams AE, Shepherd NJ, Larner-Svensson HM, Lindsay MA: Rapid changes in microRNA-146a expression negatively regulate the IL-1beta-induced inflammatory response in human lung alveolar epithelial cells. J Immunol 2008, 180(8):5689-5698.

68. Kuper H, Adami HO, Trichopoulos D: Infections as a major preventable cause of human cancer. J Intern Med 2000, 248(3):171-183.

69. Lin Y, Bai L, Chen W, Xu S: The NF-kappaB activation pathways, emerging molecular targets for cancer prevention and therapy. Expert Opin Ther Targets 2010, 14(1):45-55.

70. Takamizawa J, Konishi H, Yanagisawa K, Tomida S, Osada H, Endoh H, Harano T, Yatabe Y, Nagino M, Nimura Y, Mitsudomi T, Takahashi T: Reduced expression of the let-7 microRNAs in human lung cancers in association with shortened postoperative survival. Cancer Res 2004, 64(11):3753-3756.

71. Trang P, Medina PP, Wiggins JF, Ruffino L, Kelnar K, Omotola M, Homer R, Brown D, Bader AG, Weidhaas JB, Slack FJ: Regression of murine lung tumors by the let-7 microRNA. Oncogene 2010, 29(11):1580-1587.

72. He L, Thomson JM, Hemann MT, Hernando-Monge E, Mu D, Goodson S, Powers S, Cordon-Cardo C, Lowe SW, Hannon GJ, Hammond SM: A microRNA polycistron as a potential human oncogene. Nature 2005, 435(7043):828-833.

73. Ventura A, Young AG, Winslow MM, Lintault L, Meissner A, Erkeland SJ, Newman J, Bronson RT, Crowley D, Stone JR, Jaenisch R, Sharp PA, Jacks T: Targeted deletion reveals essential and overlapping functions of the miR-17 through 92 family of miRNA clusters. Cell 2008, 132(5):875-886.

74. Hayashita Y, Osada H, Tatematsu Y, Yamada H, Yanagisawa K, Tomida S, Yatabe Y, Kawahara K, Sekido Y, Takahashi T: A polycistronic microRNA cluster, miR-17-92, is overexpressed in human lung cancers and enhances cell proliferation. Cancer Res 2005, 65(21):9628-9632.

75. Liu B, Peng XC, Zheng XL, Wang J, Qin YW: MiR-126 restoration downregulate VEGF and inhibit the growth of lung cancer cell lines in vitro and in vivo. Lung Cancer 2009, 66:169-175.

76. Yu SL, Chen HY, Chang GC, Chen CY, Chen HW, Singh S, Cheng CL, Yu CJ, Lee YC, Chen HS, Su TJ, Chiang CC, Li HN, Hong QS, Su HY, Chen CC, Chen WJ, Liu CC, Chan WK, Li KC, Chen JJ, Yang PC: MicroRNA signature predicts survival and relapse in lung cancer. Cancer Cell 2008, 13(1):48-57.

77. Yu L, Todd NW, Xing L, Xie Y, Zhang H, Liu Z, Fang H, Zhang J, Katz RL, Jiang F: Early detection of lung adenocarcinoma in sputum by a panel of microRNA markers. Int J Cancer 2010.

78. Mitchell PS, Parkin RK, Kroh EM, Fritz BR, Wyman SK, PogosovaAgadjanyan EL, Peterson A, Noteboom J, O'Briant KC, Allen A, Lin DW, Urban N, Drescher CW, Knudsen BS, Stirewalt DL, Gentleman R, Vessella RL, Nelson PS, Martin DB, Tewari M: Circulating microRNAs as stable bloodbased markers for cancer detection. Proc Natl Acad Sci USA 2008, 105(30):10513-10518

79. Bishop JA, Benjamin H, Cholakh H, Chajut A, Clark DP, Westra WH: Accurate classification of non-small cell lung carcinoma using a novel microRNAbased approach. Clin Cancer Res 2010, 16(2):610-619

80. Drummond MB, Dasenbrook EC, Pitz MW, Murphy DJ, Fan E: Inhaled corticosteroids in patients with stable chronic obstructive pulmonary disease: a systematic review and meta-analysis. JAMA 2008, 300(20):2407-2416

81. Pauwels RA, Buist AS, Calverley PM, Jenkins CR, Hurd SS: Global strategy for the diagnosis, management, and prevention of chronic obstructive pulmonary disease. NHLBI/WHO Global Initiative for Chronic Obstructive Lung Disease (GOLD) Workshop summary. Am J Respir Crit Care Med 2001, 163(5):1256-1276.

82. Murray CJ, Lopez AD: Alternative projections of mortality and disability by cause 1990-2020: Global Burden of Disease Study. Lancet 1997, 349(9064):1498-1504.
83. Decramer M, Rennard S, Troosters T, Mapel DW, Giardino N, Mannino D, Wouters E, Sethi S, Cooper CB: COPD as a lung disease with systemic consequences-clinical impact, mechanisms, and potential for early intervention. COPD 2008, 5(4):235-256.

84. Oudijk EJ, Gerritsen WB, Nijhuis EH, Kanters D, Maesen BL, Lammers JW, Koenderman $\mathrm{L}$ : Expression of priming-associated cellular markers on neutrophils during an exacerbation of COPD. Respir Med 2006, 100(10):1791-1799.

85. Izzotti A, Calin GA, Arrigo P, Steele VE, Croce CM, De Flora S: Downregulation of microRNA expression in the lungs of rats exposed to cigarette smoke. FASEB J 2009, 23(3):806-812.

86. Izzotti A, Calin GA, Steele VE, Croce CM, De Flora S: Relationships of microRNA expression in mouse lung with age and exposure to cigarette smoke and light. FASEB J 2009, 23(9):3243-3250.

87. Schembri F, Sridhar S, Perdomo C, Gustafson AM, Zhang X, Ergun A, Lu J, Liu G, Bowers J, Vaziri C, Ott K, Sensinger K, Collins JJ, Brody JS, Getts R, Lenburg ME, Spira A: MicroRNAs as modulators of smoking-induced gene expression changes in human airway epithelium. Proc Natl Acad Sci USA 2009, 106(7):2319-2324

88. Jardim MJ, Fry RC, Jaspers I, Dailey L, Diaz-Sanchez D: Disruption of microRNA expression in human airway cells by diesel exhaust particles is linked to tumorigenesis-associated pathways. Environ Health Perspect 2009, 117(11):1745-1751.

89. Masoli M, Beasley R: Asthma exacerbations and inhaled corticosteroids. Lancet 2004, 363(9416):1236.

90. Miller RL, Ho SM: Environmental epigenetics and asthma: current concepts and call for studies. Am J Respir Crit Care Med 2008, 177(6):567-573.

91. Robinson D, Hamid Q, Bentley A, Ying S, Kay AB, Durham SR: Activation of CD4+ T cells, increased TH2-type cytokine mRNA expression, and eosinophil recruitment in bronchoalveolar lavage after allergen inhalation challenge in patients with atopic asthma. J Allergy Clin Immunol 1993, 92(2):313-324

92. Wills-Karp M: Immunologic basis of antigen-induced airway hyperresponsiveness. Annu Rev Immunol 1999, 17:255-281.

93. Seguin RM, Ferrari N: Emerging oligonucleotide therapies for asthma and chronic obstructive pulmonary disease. Expert Opin Investig Drugs 2009, 18(10):1505-1517.

94. Lu TX, Munitz A, Rothenberg ME: MicroRNA-21 is up-regulated in allergic airway inflammation and regulates IL-12p35 expression. I Immunol 2009, 182(8):4994-5002.

95. Gately MK, Renzetti LM, Magram J, Stern AS, Adorini L, Gubler U, Presky DH: The interleukin-12/interleukin-12-receptor system: role in normal and pathologic immune responses. Annu Rev Immunol 1998, 16:495-521.

96. Trinchieri G: Interleukin-12 and the regulation of innate resistance and adaptive immunity. Nat Rev Immunol 2003, 3(2):133-146.

97. Chiba Y, Tanabe M, Goto K, Sakai H, Misawa M: Down-regulation of miR133a contributes to up-regulation of Rhoa in bronchial smooth muscle cells. Am J Respir Crit Care Med 2009, 180(8):713-719.

98. Chiba Y, Takada Y, Miyamoto S, MitsuiSaito M, Karaki H, Misawa M: Augmented acetylcholine-induced, Rho-mediated Ca2+ sensitization of bronchial smooth muscle contraction in antigen-induced airway hyperresponsive rats. Br J Pharmacol 1999, 127(3):597-600.

99. Chiba Y, Ueno A, Shinozaki K, Takeyama H, Nakazawa S, Sakai H, Misawa M: Involvement of RhoA-mediated Ca2+ sensitization in antigen-induced bronchial smooth muscle hyperresponsiveness in mice. Respir Res 2005, 6:4.

100. Williams AE, Larner-Svensson H, Perry MM, Campbell GA, Herrick SE, Adcock IM, Erjefalt JS, Chung KF, Lindsay MA: MicroRNA expression profiling in mild asthmatic human airways and effect of corticosteroid therapy. PLoS One 2009, 4(6)::5889.

101. World Health Organization and Cystic Fibrosis Associations Worldwide: The molecular genetic epidemiology of cystic fibrosis. Report of a joint meeting of WHO/ECFTN/ICF(M)A/ECFS. [http://www.who.int/genomics/ publications/en/HGN_WB_04.02_report.pdf].

102. Gibson RL, Burns JL, Ramsey BW: Pathophysiology and management of pulmonary infections in cystic fibrosis. Am J Respir Crit Care Med 2003, 168(8):918-951.

103. Kerem B, Rommens JM, Buchanan JA, Markiewicz D, Cox TK, Chakravarti A, Buchwald M, Tsui LC: Identification of the cystic fibrosis gene: genetic analysis. Science 1989, 245(4922):1073-1080. 
104. Riordan JR, Rommens JM, Kerem B, Alon N, Rozmahel R, Grzelczak Z, Zielenski J, Lok S, Plavsic N, Chou JL, et al: Identification of the cystic fibrosis gene: cloning and characterization of complementary DNA. Science 1989, 245(4922):1066-1073.

105. Kreindler JL: Cystic fibrosis: exploiting its genetic basis in the hunt for new therapies. Pharmacol Ther 2010, 125(2):219-229.

106. Rowe SM, Miller S, Sorscher EJ: Cystic fibrosis. N Engl J Med 2005, 352(19):1992-2001.

107. Greene CM, Carroll TP, Smith SG, Taggart CC, Devaney J, Griffin S, O'Neill SJ, McElvaney NG: TLR-induced inflammation in cystic fibrosis and noncystic fibrosis airway epithelial cells. J Immunol 2005, 174(3):1638-1646.

108. Carroll TP, Greene CM, Taggart CC, Bowie AG, O'Neill SJ, McElvaney NG: Viral inhibition of IL-1- and neutrophil elastase-induced inflammatory responses in bronchial epithelial cells. J Immunol 2005, 175(11):7594-7601.

109. Griese M, Kappler M, Gaggar A, Hartl D: Inhibition of airway proteases in cystic fibrosis lung disease. Eur Respir J 2008, 32(3):783-795.

110. Taggart CC, Greene CM, Carroll TP, O'Neill SJ, McElvaney NG: Elastolytic proteases: inflammation resolution and dysregulation in chronic infective lung disease. Am J Respir Crit Care Med 2005, 171(10):1070-1076.

111. Walsh DE, Greene CM, Carroll TP, Taggart CC, Gallagher PM, O'Neill SJ, McElvaney NG: Interleukin-8 up-regulation by neutrophil elastase is mediated by MyD88/IRAK/TRAF-6 in human bronchial epithelium. J Biol Chem 2001, 276(38):35494-35499.

112. Oglesby IK, Bray IM, Chotirmall SH, Stallings RL, O'Neill SJ, McElvaney NG, Greene CM: miR-126 is downregulated in cystic fibrosis airway epithelial cells and regulates TOM1 expression. J Immunol 2010, 184(4):1702-1709.

113. Harris TA, Yamakuchi M, Ferlito M, Mendell JT, Lowenstein CJ: MicroRNA126 regulates endothelial expression of vascular cell adhesion molecule 1. Proc Natl Acad Sci USA 2008, 105(5):1516-1521.

114. Crawford M, Brawner E, Batte K, Yu L, Hunter MG, Otterson GA, Nuovo G, Marsh CB, Nana-Sinkam SP: MicroRNA-126 inhibits invasion in non-small cell lung carcinoma cell lines. Biochem Biophys Res Commun 2008, 373(4):607-612.

115. Baskerville S, Bartel DP: Microarray profiling of microRNAs reveals frequent coexpression with neighboring miRNAs and host genes. RNA 2005, 11(3):241-247.

116. Wang Y, Weng T, Gou D, Chen Z, Chintagari NR, Liu L: Identification of rat lung-specific microRNAs by micoRNA microarray: valuable discoveries for the facilitation of lung research. BMC Genomics 2007, 8:29.

117. Brissoni B, Agostini L, Kropf M, Martinon F, Swoboda V, Lippens S, Everett H, Aebi N, Janssens S, Meylan E, Felberbaum-Corti M, Hirling H, Gruenberg J, Tschopp J, Burns K: Intracellular trafficking of interleukin-1 receptor I requires Tollip. Curr Biol 2006, 16(22):2265-2270.

118. Katoh Y, Shiba Y, Mitsuhashi H, Yanagida Y, Takatsu H, Nakayama K: Tollip and Tom 1 form a complex and recruit ubiquitin-conjugated proteins onto early endosomes. I Biol Chem 2004, 279(23):24435-24443.

119. Yamakami M, Yoshimori T, Yokosawa H: Tom1, a VHS domain-containing protein, interacts with tollip, ubiquitin, and clathrin. J Biol Chem 2003, 278(52):52865-52872.

120. Mattes J, Collison A, Plank M, Phipps S, Foster PS: Antagonism of microRNA-126 suppresses the effector function of TH2 cells and the development of allergic airways disease. Proc Natl Acad Sci USA 2009, 106(44):18704-18709.

121. Brunner C, Sindrilaru A, Girkontaite I, Fischer KD, Sunderkotter C, Wirth T: BOB.1/OBF.1 controls the balance of TH1 and TH2 immune responses. EMBO J 2007, 26(13):3191-3202.

122. Lichtinger M, Ingram R, Hornef M, Bonifer C, Rehli M: Transcription factor PU.1 controls transcription start site positioning and alternative TLR4 promoter usage. J Biol Chem 2007, 282(37):26874-26883.

123. Pottier N, Maurin T, Chevalier B, Puissegur MP, Lebrigand K, RobbeSermesant K, Bertero T, Lino Cardenas CL, Courcot E, Rios G, Fourre S, LoGuidice JM, Marcet B, Cardinaud B, Barbry P, Mari B: Identification of keratinocyte growth factor as a target of microRNA-155 in lung fibroblasts: implication in epithelial-mesenchymal interactions. PLoS One 2009, 4(8):e6718

124. Pandit KV, Corcoran D, Yousef H, Yarlagadda M, Tzouvelekis A, Gibson KF, Konishi K, Yousem SA, Singh M, Handley D, Richards T, Selman M, Watkins SC, Pardo A, Ben-Yehudah A, Bouros D, Eickelberg O, Ray P Benos PV, Kaminski N: Inhibition and role of let-7d in idiopathic pulmonary fibrosis. Am J Respir Crit Care Med 2010, 182(2):220-229.
125. Liu G, Friggeri A, Yang Y, Milosevic J, Ding Q, Thannickal VJ, Kaminski N, Abraham E: miR-21 mediates fibrogenic activation of pulmonary fibroblasts and lung fibrosis. J Exp Med 2010, 207(8):1589-1597.

126. Starczynowski DT, Kuchenbauer F, Argiropoulos B, Sung S, Morin R, Muranyi A, Hirst M, Hogge D, Marra M, Wells RA, Buckstein R, Lam W, Humphries RK, Karsan A: Identification of miR-145 and miR-146a as mediators of the 5q- syndrome phenotype. Nat Med 2010, 16(1):49-58.

doi:10.1186/1465-9921-11-148

Cite this article as: Oglesby et al:: MicroRNAs in inflammatory lung disease - master regulators or target practice? Respiratory Research 2010 11:148.

\section{Submit your next manuscript to BioMed Central and take full advantage of:}

- Convenient online submission

- Thorough peer review

- No space constraints or color figure charges

- Immediate publication on acceptance

- Inclusion in PubMed, CAS, Scopus and Google Scholar

- Research which is freely available for redistribution

Submit your manuscript at www.biomedcentral.com/submit
Biomed Central 